\title{
Keanekaragaman dan Kerapatan Rumput Laut Alami Perairan Pulau Serangan Denpasar Bali
}

\author{
Ni Desak Putu Dita Herlinawati a*, I Wayan Arthana a, Ayu Putu Wiweka Krisna Dewi a \\ a Program Studi Manajemen Sumberdaya Perairan, Fakultas Kelautan dan Perikanan, Universitas Udayana, Bukit Jimbaran, Bali-Indonesia \\ *Penulis koresponden. Tel.: +62-818-0210-4497 \\ Alamat e-mail: desakdita94@yahoo.com
}

Diterima (received) 12 Juni 2017; disetujui (accepted) 22 Agustus 2017; tersedia secara online (available online) 24 Agustus 2017

\begin{abstract}
Serangan Island was a costal area located in the Serangan village, South Denpasar district, near with Sanur and Nusa Dua tourism area. Serangan beach has a biodiversity such as natural macroalgae. This study was conducted in January 2017 at the seaweed cultivation area with the aims of research were to know the variety and density of macroalgae. The method used was a 1x1 m quadrat transect. Sampling was carried out during low tide. Macroalgae found in the area, consist of 12 species namely Ulva lactuca, Chaetomorpha linum. Chaetomorpha aera, Padina australis, Sargassum fluitans, Turbinaria ornate, Gelidium sp., Hypnea cornuta, Hypnea spicifera, Gracilaria salicornia, Acanthophora spicifera, Halimeda opuntia. Those species were belonging to 3 divisi namely Chlorophyta, Phaeophyta, Rhodophyta. The highest density of macroalgae was Padina australis while the lowest density was Chaetomorpha linum. Type of dominated macroalgae was from a group of Phaeophyta (brown algae) with highest dominance from the species of Padina australis. Water quality namely acidity $(\mathrm{pH})$ was in the range of 7.54 to 7.75 , salinity of $31.33-32.00 \mathrm{ppt}$, the water temperature was $26.50-27.30^{\circ} \mathrm{C}$, which all was categorized as the optimal parameters for the growth of macroalgae. Assosiation of biota found were 9 species namely fish of larva, Cypraea lynx (Molusca), Emerita sp., Halodule sp., Synapta maculate, Enhalus acoroides, Cymodocea serrulata, Hermit crab, Ophiuroidea sp. The conditions coastal waters substrate was varied from white sand stone type to stony type by coral pieces.
\end{abstract}

Keyword: Chlorophyta; Macroalgae; Phaeophyta; Rhodophyta; Serangan island

\begin{abstract}
Abstrak
Pulau Serangan merupakan wilayah pesisir yang terletak di Kelurahan Serangan Kecamatan Denpasar Selatan, yang berdekatan dengan kawasan wisata Sanur dan Nusa Dua. Perairan Pulau Serangan memiliki keanekaragaman hayati seperti rumput laut alami, Penelitian mengenai rumput laut alami dilakukan untuk mengetahui keanekaragaman dan kerapatannya. Penelitian ini dilaksanakan pada bulan Januari 2017 di bagian perairan yang terdapat kegiatan budidaya rumput laut. Penelitian mencakup tentang kelimpahan dan dominansi jenis rumput laut alami. Metode yang digunakan yaitu Transek Kuadrat 1x1 meter. Rumput laut alami yang ditemukan di perairan Pulau Serangan adalah 12 spesies yaitu Ulva lactuca, Chaetomorpha linum. Chaetomorpha aera, Padina australis, Sargassum fluitans, Turbinaria ornata, Gelidium sp., Hypnea cornuta, Hypnea spicifera, Gracilaria salicornia, Acanthophora spicifera, Halimeda opuntia yang tergolong ke dalam 3 divisi yaitu Chlorophyta, Phaeophyta, Rhodophyta. Kerapatan rumput laut alami tertinggi adalah Padina australis, sedangkan kerapatan terendah adalah Chaetomorpha linum. Jenis makroalga yang mendominansi perairan Pulau Serangan di daerah budidaya rumput laut yaitu kelompok Phaeophyta (alga coklat) dengan dominansi tertinggi jenis Padina australis. Kualitas perairan derajat keasaman $(\mathrm{pH})$ berada pada kisaran 7,547,75, salinitas berada pada kisaran $31,33-32,00$ ppt dan suhu perairan berada pada kisaran $26,50-27,30^{\circ} \mathrm{C}$, parameter tersebut dikategorikan optimal untuk pertumbuhan makroalga. Biota asosiasi yang ditemukan sebanyak 9 spesies yaitu larva ikan, Cypraea lynx (Molusca). Undur Laut Emerita sp., Lamun Halodule sp., Synapta maculate, Enhalus acoroides, Cymodocea serrulata, Klomang, Bintang mengular Ophiuroidea sp. Kondisi substrat perairan laut Pulau Serangan bervariasi antara pasir putih sampai dengan berbatu hasil pecahan karang.
\end{abstract}

Kata Kunci: Makroalga; Chlorophyta; Phaeophyta; Rhodophyta; Pulau Serangan 


\section{Pendahuluan}

Potensi rumput laut di Bali tersebar di beberapa daerah meliputi perairan Nusa Penida Kabupaten Klungkung, Kabupaten Badung, Kabupaten Buleleng dan Kota Denpasar (Poeloengasih et al., 2014; Arthana et al., 2017). Petani rumput laut di Bali terhimpun dalam 109 kelompok dengan anggota yang berjumlah 3.350 orang petani (DKP Provinsi Bali, 2009).

Keberhasilan pertumbuhan rumput laut alami sangat ditentukan oleh kondisi fisik serta kimia perairan. Kondisi perairan yang optimal dapat menghasilkan pertumbuhan rumput laut yang optimal pula. Faktor ekologi yang mempengaruhi pertumbuhan rumput laut alami antara lain faktor fisika yaitu suhu, intensitas cahaya, kedalaman dan arus, faktor kimia meliputi salinitas, $\mathrm{pH}$, dan nutrien, faktor biologi meliputi ikan herbivora serta kondisi rumput laut itu sendiri (Lyons et al., 2010; Yu et al., 2013; Gutow et al., 2016). Menurut Papalia dan Arfah (2013) dasar perairan pasir putih kasar yang bercampur lumpur dan dengan pecahan karang cocok untuk pertumbuhan rumput laut alami.

Rumput laut alami mengalami gangguan pertumbuhan, karena adanya beberapa aktivitas yang meliputi aktivitas pariwisata, diving, snorkeling dan budidaya rumput laut (Silva et al., 2012). Perkembangan pariwisata ini juga berpengaruh terhadap kenaikan tingkat pencemaran lingkungan perairannya (Prabhakaran et al., 2013; Li et al., 2016). Beberapa industri pariwisata masih ada yang membuang limbah ke perairan, serta adanya aktivitas masyarakat yang membuang sampah sembarangan, menyebabkan pertumbuhan rumput laut alami menjadi tidak optimal (Moussiopoulos et al., 2010). Aktivitas budidaya rumput laut di Pulau Serangan dapat mempengaruhi keberadaan pertumbuhan rumput laut alami, akan timbul persaingan dalam penyerapan unsur hara antara rumput laut budidaya dengan rumput laut alami, sehingga pertumbuhan rumput laut budidaya lebih cepat dari pada pertumbuhan rumput laut alami. Tujuan penelitian ini adalah untuk mengetahui keanekaragaman dan kerapatan rumput laut alami, dan untuk mengetahui pengaruh ekologi terhadap pertumbuhan rumput laut alami.

\section{Metode Penelitian}

\subsection{Metode Pengumpulan Data}

Penelitian ini menggunakan metode observasi lapangan secara langsung dan analisis
Laboratorium. Data yang digunakan pada penelitian adalah data primer yaitu data yang diperoleh dari pemeriksaan secara berkala terhadap keanekaragaman dan kerapatan rumput laut alami secara langsung di masing-masing stasiun yang telah ditentukan di perairan Pantai Pulau Serangan.

\subsection{Waktu dan Tempat Penelitian}

Penelitian ini dilaksanakan di perairan Pulau Serangan Bali (Gambar 1). Pengambilan data dilaksanakan pada bulan Januari 2017.

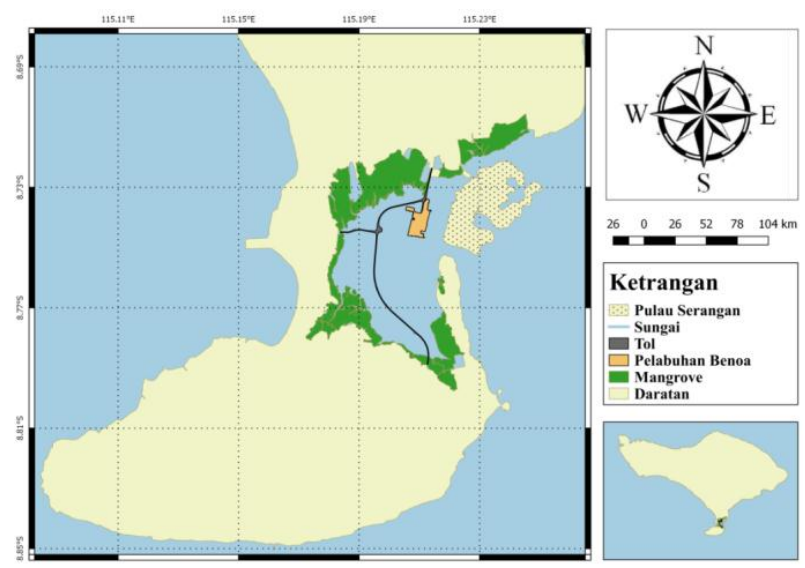

Gambar 1. Peta Lokasi Penelitian

\subsection{Metode Penelitian}

Penelitian keanekaragaman dan kerapatan rumput laut alami menggunakan metode kuadrat transek 1x1 m. Pengamatan dilakukan pada 5 titik pengamatan dimasing-masing stasiun. Jarak antara masing- masing stasiun yaitu $50 \mathrm{~m}$ yang dipindahkan secara pararel. Parameter yang diamati keanekaragaman dan kerapatan rumput laut alami, biota yang berasosiasi di perairan tersebut. Parameter kualitas air yang diamati yaitu $\mathrm{pH}$, suhu, salinitas, nitrat dan fosfat.

\subsection{Alat dan Bahan}

Alat dan bahan yang digunakan dalam penelitian ini adalah $\mathrm{pH}$ meter, GPS, meteran, transek dan refraktometer. Alat dan bahan yang digunakan tersaji pada Tabel 1.

\subsection{Analisa Data}

Rumus yang digunakan dalam analisis data pada penelitian ini adalah: 
Tabel 1

Alat dan Bahan

\begin{tabular}{ll}
\hline Alat dan Bahan & Fungsi \\
\hline Thermometer & Mengukur Suhu Perairan \\
Transek Kuadran & Mengamati Sampel \\
pH Meter & Mengukur pH Perairan \\
Rumput Laut & Sampel Penelitian \\
Aquades & Mensterilkan alat \\
Tissue & Membersihkan alat \\
Botol Sampel Air & Meletakkan air sampel \\
Meteran & Mengukur jarak lokasi \\
Kamera Digital & Mendokumentasikan \\
\hline
\end{tabular}

2.5.1 Kerapatan dan Kelimpahan Jenis Rumput Laut alami

Mencatat semua jenis dan masing-masing dalam bentuk individu maupun koloni dan menghitung kerapatan atau kelimpahan jenis dalam satu komunitas dengan rumus Brower (Palallo, 2013) :

$$
K i=\frac{n i}{A}
$$

\subsubsection{Dominansi Jenis}

Untuk menghitung indeks dominansi digunakan rumus (Odum, 1993) sebagai berikut:

$$
C=\Sigma\left(\frac{n i}{A}\right) 2
$$

\section{Keterangan:}

C : Indeks dominansi

ni : Jumlah individu spesies ke-i

$\mathrm{N} \quad$ : Jumlah total spesies

Tabel 2

Kisaran Nilai Indeks Dominansi (C)

\begin{tabular}{cc}
\hline Kisaran & Kategori \\
\hline $\mathrm{D}>0,4$ & Rendah \\
$0,4<\mathrm{D}<0,6$ & Sedang \\
$\mathrm{D}>0,6$ & Tinggi \\
\hline
\end{tabular}

\subsubsection{Keanekaragaman Rumput Laut}

Keanekaragaman spesies dapat dikatakan sebagai indikasi banyaknya jenis rumput laut alami dan bagaimana penyebaran jumlah individu pada setiap jenis dan lokasi sampling. Untuk menentukan keanekaragaman dihitung dengan menggunakan formula Shannon-Weaner (Odum, 1993) berikut:

$H^{\prime}=-\Sigma p i \ln p i$

Keterangan:

$\mathrm{H}^{\prime} \quad$ : Indeks Keanekaragaman Jenis

ni : Jumlah individu jenis ke-i

$\mathrm{N}$ : Jumlah total individu

$S \quad$ : Jumlah genus penyusun komunitas

$\mathrm{Pi} \quad: \mathrm{ni} / \mathrm{N}$

\section{Tabel 3}

Kisaran stabilitas perairan berdasarkan indeks keanekaragaman $\left(\mathrm{H}^{\prime}\right)$

\begin{tabular}{cc}
\hline Kisaran & Kategori \\
\hline $\mathrm{H}^{\prime}<2,0$ & Rendah \\
$2,0<\mathrm{H}^{\prime}<3,0$ & Sedang \\
$\mathrm{H}^{\prime}>3$ & Tinggi \\
\hline
\end{tabular}

\subsubsection{Keseragaman Rumput Laut}

Keseragaman dapat dikatakan sebagai keseimbangan, yaitu komposisi individu tiap jenis yang terdapat dalam suatu komunitas (Odum, 1993), yaitu:

$$
E=\frac{H^{\prime}}{H \max }
$$

Keterangan:

E : Indeks keseragaman

$\mathrm{H}^{\prime} \quad$ : Indeks keanekaragaman

H max : Keanekaragaman spesies maksimum (ln S)

Tabel 4

Nilai Indeks Keseragaman (E)

\begin{tabular}{cc}
\hline Kisaran & Kategori \\
\hline $0,00<\mathrm{E}<0,50$ & Rendah \\
$0,50<\mathrm{E}<0,75$ & Sedang \\
$0,75<\mathrm{E}<1,00$ & Tinggi \\
\hline
\end{tabular}

\section{Hasil}

\subsection{Hasil Identifikasi Spesies Rumput laut alami}

Divisi rumput laut yang diperoleh pada semua stasiun penelitian di perairan Pulau Serangan yaitu sebanyak 3 divisi dengan jumlah spesies 
sebanyak 12 spesies. Divisi tersebut yaitu divisi Chlorophyta (alga hijau), divisi Phaeophyta (alga coklat), dan divisi Rhodophyta (alga merah). Hasil identifikasi jenis rumput laut alami dapat dilihat pada Tabel 5.

\section{Tabel 5}

Hasil Identifikasi Spesies Rumput Laut Alami

\begin{tabular}{lllc}
\hline \multicolumn{1}{c}{ Divisi } & Ordo & \multicolumn{1}{c}{ Spesies } & $\begin{array}{c}\text { Jumlah } \\
\text { Individu/m² }\end{array}$ \\
\hline Chlorophyta & Chlorophy- & Ulva lactuca & 4 \\
(Alga Hijau) & ceae & Chaetomorpha linum. & 0,2 \\
& & Chaetomorpha aera & 5,4 \\
Phaeophyta & Phaeophye- & Padina australis & 29 \\
(Alga Coklat) & cae & Sargassum fluitans. & 1 \\
& & Turbinaria ornate & 0,4 \\
& & Gelidium sp, & 0,6 \\
Rhodophyta & Rhodophy- & Hypnea cornuta. & 11,4 \\
(Alga Merah) & ceae & Hypnea spicifera. & 4 \\
& & Gracilaria salicornia & 12 \\
& & Acanthophora spicifera & 12,8 \\
& & Halimeda opuntia & 1,8 \\
\hline Total & \multirow{2}{*}{3} & 12 & 82,6 \\
\hline
\end{tabular}

Jumlah spesies yang ditemukan pada semua stasiun yaitu sebanyak 12 spesies (Tabel 5). Spesies terbanyak yang ditemukan yaitu pada divisi Rhodophyta (alga merah) sebanyak 5 spesies, spesies Acanthopora spicifera merupakan spesies yang paling banyak ditemukan. Rumput laut alami pada divisi Phaeophyta (alga coklat) ditemukan sebanyak 4 spesies, dimana spesies yang paling banyak ditemukan pada divisi ini adalah spesies Padina australis, dan pada divisi Chlorophyta (alga hijau) sebanyak 3 spesies yang paling banyak adalah spesies Chaetomorpha aera. Spesies rumput laut alami yang paling banyak ditemukan adalah spesies Padina australis dari divisi Phaeophyta (alga coklat) dengan jumlah sebanyak 29 individu/ $\mathrm{m}^{2}$.

Spesies rumput laut alami yang paling banyak ditemukan yaitu 5 spesies dari 12 spesies yang ditemukan pada masing-masing stasiun penelitian, spesies tersebut yaitu dari kelas Chlorophyta Chaetomorpha aera, Padina australis dan Acanthopora spircifera, Hypnea cornuta, Glacilaria salicornia (Gambar 2). Spesies terbanyak ditemukan di semua stasiun yaitu Padina australis sebanyak 29 individu $/ \mathrm{m}^{2}$, sedangkan untuk spesies yang paling sedikit ditemukan yaitu Chaetomorpha aera sebanyak 5,4 individu $/ \mathrm{m}^{2}$. Jumlah spesies rumput laut alami yang ditemukan pada masing-masing stasiun yaitu, stasiun I sebanyak 7 spesies, stasiun II sebanyak 6 spesies dan stasiun III sebanyak 10 spesies (Gambar 3).

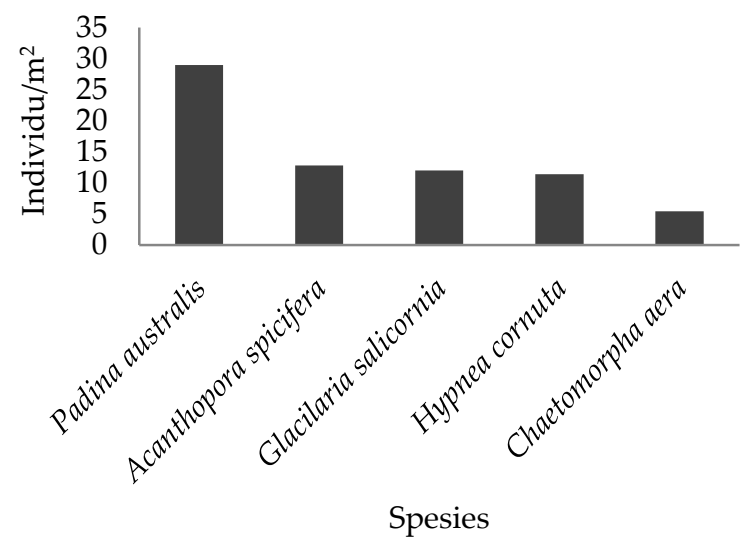

Gambar 2. Lima Spesies Rumput laut alami Paling Banyak ditemukan

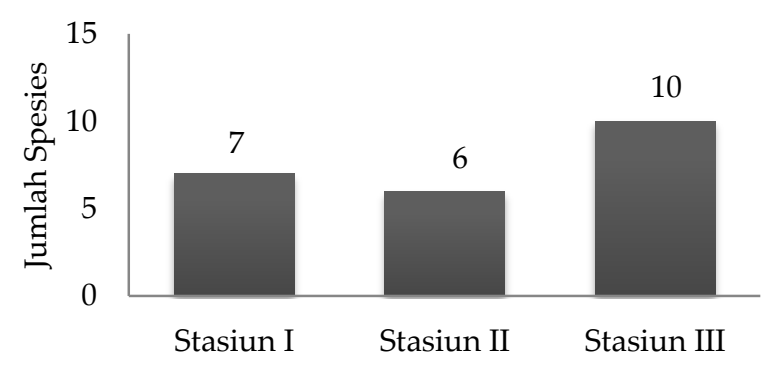

Gambar 3. Jumlah Spesies di Semua Stasiun

\subsection{Indeks Ekologi}

Berdasarkan Tabel 6, menunjukan bahwa indeks ekologi, nilai indeks keanekaragaman $\left(\mathrm{H}^{\prime}\right)$ rumput laut alami dari semua stasiun penelitian yaitu sebesar 1,5 dan nilai tersebut dikategorikan rendah. Kemudian untuk nilai indeks keseragaman (E) rumput laut alami yaitu sebesar 0,78 dan nilai tersebut dikategorikan tinggi. Sedangkan untuk nilai indeks dominansi (C) rumput laut alami yaitu sebesar 0,29 dan dikategorikan rendah.

\subsection{Parameter Kualitas air}

Pengukuran parameter kualitas air yang diamati meliputi $\mathrm{pH}$, salinitas dan suhu serta pengambilan data kandungan nitrat dan fosfat pada Perairan Pulau Serangan. Pengukuran kualitas air dilakukan secara langsung, sedangkan untuk parameter nitrat dan fosfat dilakukan insitu. Pengukuran kualitas air dilakukan pada pukul 06.00 WITA. 
Tabel 6

Indeks Ekologi Rumput Laut Alami Perairan Pulau Serangan

\begin{tabular}{lccc}
\hline \multicolumn{1}{c}{ Indeks } & Kisaran & Kategori & Nilai \\
\hline Keanekaraga- & $\mathrm{H}<2,0$ & Rendah & 1,5 \\
man $\left(\mathrm{H}^{\prime}\right)$ & $2,0<\mathrm{H}<3,0$ & Sedang & (Rendah) \\
& $\mathrm{H}>3$ & Tinggi & \\
Keseragaman & $0,00<\mathrm{E}<0,50$ & Rendah & 0,78 \\
(E) & $0,50<\mathrm{E}<0,75$ & Sedang & (Tinggi) \\
& $0,75<\mathrm{E}<1,00$ & Tinggi & \\
Dominansi & $\mathrm{D}>0,4$ & Rendah & 0,29 \\
(D) & $0,4<\mathrm{D}<0,6$ & Sedang & (Rendah) \\
& $\mathrm{D}>0,6$ & Tinggi & \\
\hline
\end{tabular}

\subsubsection{Nilai $\mathrm{pH}$}

Hasil penelitian menunjukan bahwa $\mathrm{pH}$ diperairan Pulau Serangan berkisar antara 7,54 - 7,75. pH tersebut cukup optimal untuk pertumbuhan rumput laut. Stasiun III memiliki $\mathrm{pH}$ perairan yang lebih tinggi dibandingkan stasiun I dan stasiun II, $\mathrm{pH}$ tersebut sebesar 7,73. Sedangkan untuk stasiun I sebesar 7.64 dan $\mathrm{pH}$ terendah didapatkan pada stasiun II yaitu sebesar 7,58 (Gambar 4).

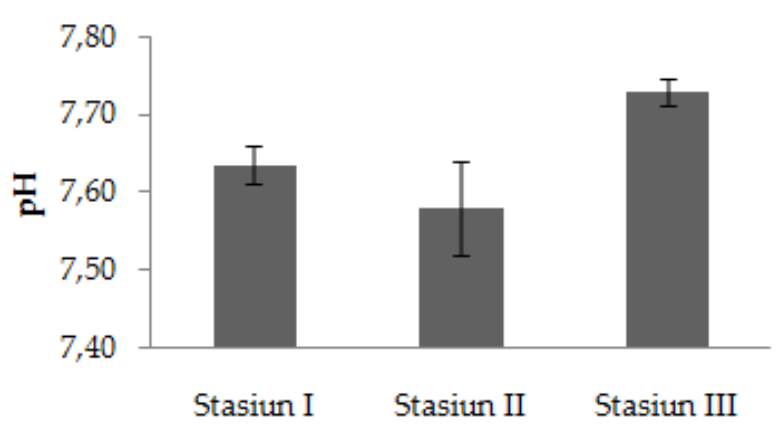

Gambar 4. Grafik rata-rata $\mathrm{pH}$ perairan Pulau Serangan

\subsubsection{Suhu}

Hasil penelitian menunjukan bahwa suhu permukaan perairan pada seluruh stasiun pengamatan berkisar $26,50-27,30^{\circ} \mathrm{C}$. Suhu tersebut cukup optimal untuk pertumbuhan rumput laut alami. Stasiun III memiliki suhu perairan yang ditinggi dibandingkan stasiun I dan stasiun II, suhu tersebut sebesar $27,7^{\circ}$ C. Suhu pada stasiun I sebesar $26,85^{\circ} \mathrm{C}$ dan stasiun II sebesar $26,67^{\circ} \mathrm{C}$ (Gambar 5).

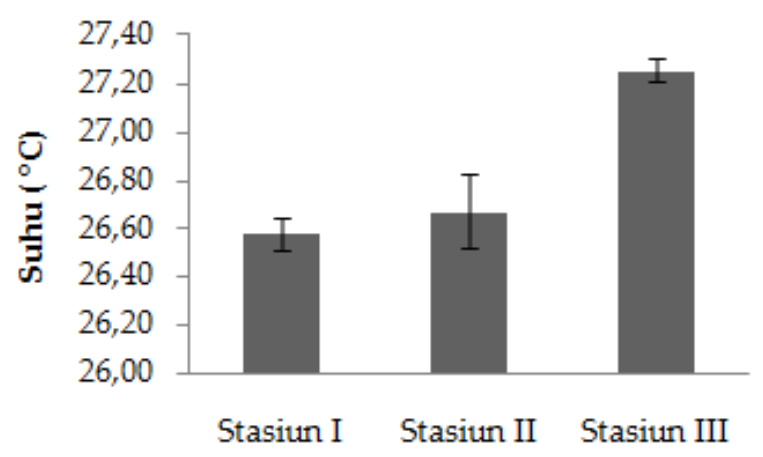

Gambar 5. Grafik rata-rata suhu perairan Pulau Serangan.

\subsubsection{Salinitas}

Hasil penelitian menunjukan bahwa salinitas diperairan Pulau Serangan berkisar 31,33-32,00 ppt. Hal tersebut menunjukan bahwa dengan salinitas 31-32 ppt maka pertumbuhan makroalga cukup optimal. Salinitas tertinggi pada stasiun III yaitu sebesar 31,55 ppt. Sedangkan untuk stasiun I yaitu sebesar 31,44 ppt dan stasiun II sebesar 31,42 (Gambar 6).

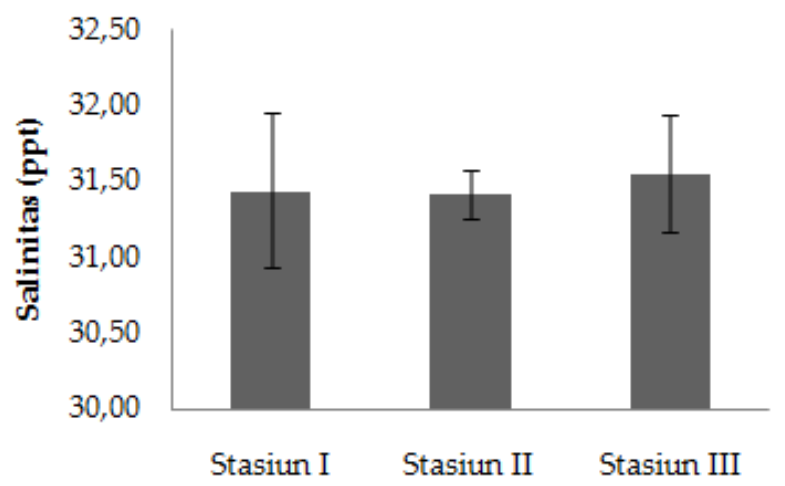

Gambar 6. Grafik rata-rata salinitas perairan Pulau Serangan

\subsection{Substrat Perairan}

Hasil penelitian menunjukan bahwa stasiun I terletak di daerah budidaya dan tidak memiliki substrat yang beragam hanya didominansi substart yang berpasir halus. Stasiun II terletak diantara daerah budidaya rumput laut dengan perairan laut Pulau Serangan dengan substrat dominan pasir berlumpur dan terdapat ekosistem lamun. Sedangkan untuk stasiun III terletak di perairan laut Pulau Serangan yang memiliki substrat pasir berbatu, terdapat pecahan-pecahan 
karang mati disekitar lokasi tersebut sehingga didominansi oleh Padina australis (Tabel 7)..

Tabel 7

Substrat Perairan Pulau Serangan

\begin{tabular}{cl}
\hline Stasiun & \multicolumn{1}{c}{ Substrat } \\
\hline I & $\begin{array}{l}\text { Substrat berpasir halus dan } \\
\text { terdapat ekosistem lamun } \\
\text { disekitarnya, }\end{array}$ \\
II & $\begin{array}{l}\text { Substrat pasir putih kasar } \\
\text { berlumpur, } \\
\text { ekosistem padang lamun } \\
\text { disekitarnya }\end{array}$ \\
III & $\begin{array}{l}\text { Substrat berbatu dan pasir } \\
\text { berbatu serta terdapat } \\
\text { pecahan batu karang }\end{array}$ \\
&
\end{tabular}

\subsection{Biota Berasosiasi}

Hasil dari pengamatan terdapat beberapa biota perairan laut yang terdapat di perairan Pulau Serangan dari masing-masing stasiun, biota perairan tersebut flora maupun fauna yang berasosiasi, terdapat berbagai jenis lamun dan molusca maupun crustacea, biota tersebut berada diantara thallusdari rumput laut alami dengan cara melekat maupun berada disekitar makroalga untuk melindungi diri maupun mencari makanan. Terdapat beberapa jenis spesies biota perairan dari masing masing stasiun yaitu, larva ikan, Cypraea lynx (Molusca). Undur Laut Emerita sp, Lamun Halodule sp., Synapta maculata, Enhalus acoroides, Cymodocea serrulata, Klomang, Bintang mengular Ophiuroidea sp. Selangkapnya dapat di lihat pada Gambar 7.

\section{Pembahasan}

\subsection{Komposisi Jenis Rumput Laut Alami}

Persentase spesies rumput laut alami tertinggi yang ditemukan pada semua stasiun di perairan Pulau Serangan yaitu spesies Padina australis dari kelas Phaeophyta (alga coklat). Makroalga jenis Phaeophyta banyak tumbuh di daerah tropis (Sukiman dkk., 2014). Spesies tersebut paling banyak ditemukan pada stasiun III, hal ini diduga karena spesies ini dapat tumbuh pada substrat berbatu dan substrat pecahan karang mati dan gerakan air yang tenang sehingga alga tersebut dapat tumbuh dan melekat dengan baik. Padina australis menyukai habitat di sekitar genangan air yang tenang di atas substrat batu karang pantai

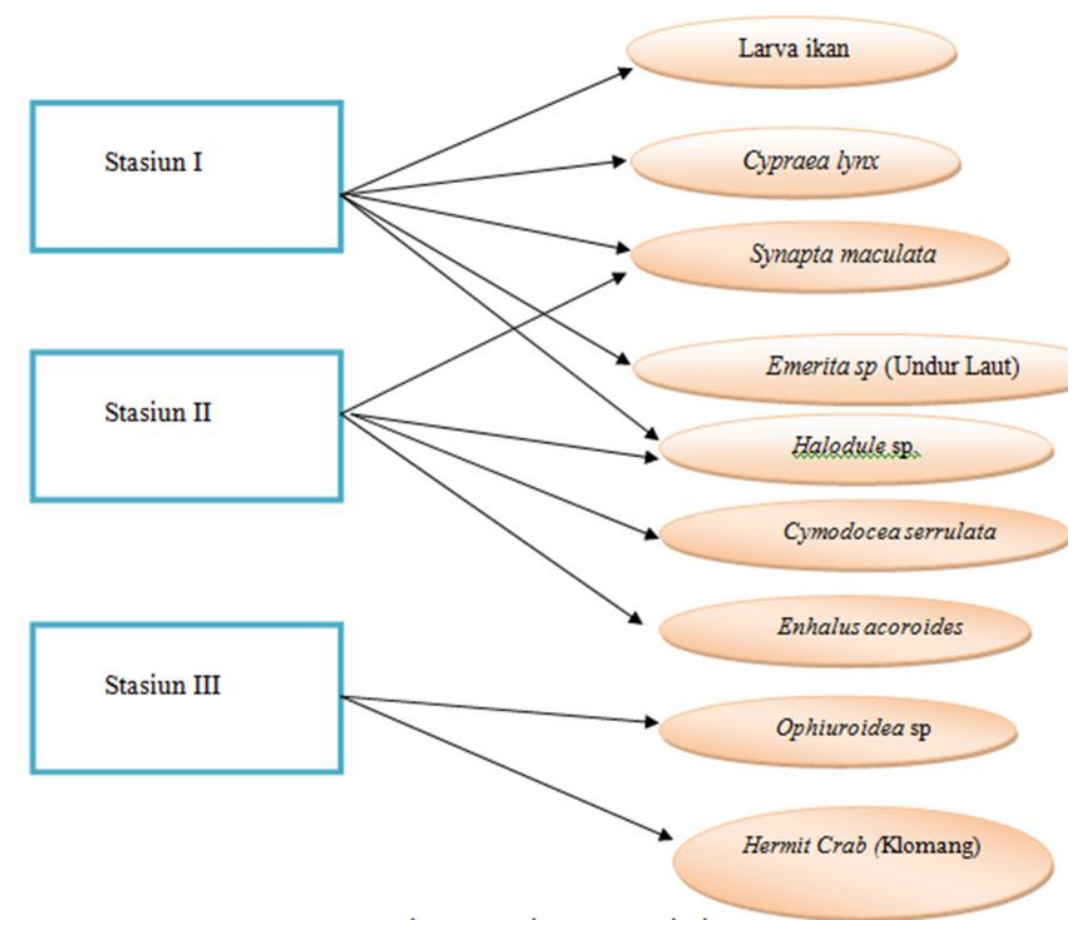

Gambar 7. Biota Berasosiasi 
(Setyawan dkk., 2014). Stasiun II banyak ditemukan spesies Gracilaria salicornia, hal ini dikarenakan spesies tersebut dapat tumbuh pada habitat yang berpasir dan di daerah pasang surut (Langoy et al., 2011).

\subsection{Kerapatan Rumput Laut Alami}

Spesies rumput laut alami yang ditemukan di perairan Pulau Serangan yaitu sebanyak 12 spesies dengan kerapatan tertinggi pada spesies Padina australis. Spesies rumput laut alami yang ditemukan di Pulau Serangan lebih sedikit jika dibandingkan dengan rumput laut alami yang ditemukan di perairan Laut Tamil Nadu, India yaitu sebanyak 57 spesies (Sahayaraj et al., 2015). Rumput laut alami yang ditemukan Pantai Drini Yogyakarta yaitu sebanyak 18 spesies (Pratama et al., 2015), rumput laut alami ditemukan di kepulauan Anambas adalah 18 spesies (Kadi, 2009) dan sedangkan untuk rumput laut alami yang ditemukan sepanjang Pantai Gunung Kidul sebanyak 13 spesies (Nurmiyati, 2013).

\subsection{Indeks Keanekaragaman $\left(H^{\prime}\right)$}

Nilai indeks keanekaragaman dikategorikan rendah. Keanekaragaman jenis ditentukan oleh keanekaragaman habitat (substrat). Kestabilan, kekerasan, tekstur dan porositas substrat penting artinya bagi pertumbuhan yang mendukung kelimpahanya. Oleh karena itu keanekaragaman jenis makroalga di daerah pasang surut (intertidal) antara lain disebabkan pula oleh heterogenitas substratnya. Di tempat-tempat yang memiliki substrat pecahan karang batu mati, karang massif dan pasir yang lebih stabil mempunyai keanekaragaman makroalga yang tinggi dibandingkan dengan tempat-tempat yang hanya bersubstrat pasir dan lumpur. Jenis makroalga yang didapat umumnya mempunyai keanekaragaman yang tinggi pada perairan yang masih dalam kondisi baik dan sebaliknya kondisi perairan yang kurang baik akan menunjukkan keanekaragaman lebih rendah.

\subsection{Indeks Keseragaman (E)}

Indeks keseragaman merupakan suatu pola sebaran biota laut, yaitu merata atau tidak. Nilai indeks keseragaman di stasiun I dan II tinggi pada perairan Pulau Serangan. Jika nilai tinggi maka setiap jenis rumput laut alami dalam kondisi yang merata atau seragam. Keseragaman yang tinggi mengindikasikan bahwa jumlah antara rumput laut alami yang ditemukan tidak berbeda jauh (merata) ini juga dibuktikan dengan nilai dominansi yang rendah. Keseragaman dapat dikatakan keseimbangan, relatif sama, karena komposisi individu setiap spesies terdapat dalam suatu komunitas. Semakin tinggi keseragaman (E), maka semakin kecil nilai dominansi jenis (Palallo, 2013).

\subsection{Indeks Dominansi (C)}

Berdasarkan hasil perhitungan Indeks Dominansi (C), setiap stasiun memiliki hasil yang berbeda tergantung pada jumlah spesies yang ditemukan dan kelimpahan spesies setiap stasiunnya. Secara keseluruhan pada lokasi penelitian di daerah budidaya rumput laut perairan Pulau Serangan nilai indeks dominansi sebesar 0,29 . Nilai tersebut masih dikategorikan rendah dan mengindikasikan pada lokasi tersebut tidak didominansi oleh satu spesies. Apabila nilai indeks dominansi cenderung mendekati satu maka perairan tersebut didominansi oleh satu spesies. Tingginya nilai indeks dikarenakan jumlah spesies yang ditemukan tidak beragam, selain itu kerapatan yang didapatkan pada satu spesies cenderung tinggi (Odum, 1993). Rendahnya nilai dominansi tersebut disebabkan oleh di daerah perairan Pulau Serangan tidak ada spesies rumput laut alami yang mendominansi dan pesebaran spesies tidak merata. Adanya jenis yang mendominansi dapat dipengaruhi oleh persaingan antara tumbuhan yang ada.

\subsection{Parameter Kualitas Perairan}

Berdasarkan hasil pengukuran kualitas perairan menunjukan kondisi perairan Pulau Serangan masih dalam kondisi yang baik. Rata-rata $\mathrm{pH}$ pada masing-masing stasiun didaerah budidaya rumput laut Pulau Serangan berada pada kisaran 7,54-7,75 (Gambar 4). Nilai tersebut masih berada pada kisaran yang normal untuk pertumbuhan makroalga. Menurut Pallalo (2013), pengaruh pH bagi organisme sangat besar dan penting, kisaran pH 6 - 9 merupakan kisaran optimal dalam suatu perairan. Sedangkan menurut Burdames (2014), hampir semua alga dapat hidup pada kisaran $\mathrm{pH}$ 6,8 - 9,6, sehingga $\mathrm{pH}$ tidak menjadi masalah bagi pertumbuhannya. Kandungan salinitas di Perairan Pulau Serangan di daerah budidaya rumput laut 
menunjukan pada kirasan 30-32 ppt (Gambar 5). Kandungan salinitas pada kisaran tersebut masih normal untuk keberlangsungan pertumbuhan rumput laut alami di Perairan Pulau Serangan.

Kisaran rata-rata suhu di perairan Pulau Serangan berkisar antara 26,50-27,30 C dengan suhu pada kisaran tersebut rumput laut alami masih tetap dapat tumbuh dengan normal dan optimal (Gambar 6). Menurut Palallo (2013), pertumbuhan yang baik untuk alga di daerah tropis adalah $20-30^{\circ} \mathrm{C}$.

Berdasarkan hasil pengukuran pada lokasi penelitian menunjukan bahwa kandungan nitrat sebesar 0,92 $\mathrm{mg} / \mathrm{l}$, hasil pengukuran kandungan fosfat didapatkan sebesar $0,86 \mathrm{mg} / \mathrm{l}$, hal ini diduga bahwa hasil kandungan nitrat dan fosfat yang ditemukan di perairan Pulau Serangan mendukung pertumbuhan rumput laut alami dengan optimal. Kehadiran makroalga di perairan ini ditentukan oleh struktur subastrat yang stabil, kondisi perairan dan musim (Arfah dan Patty, 2014).

\subsection{Biota Berasosiasi}

Spesies biota perairan yang banyak ditemukan yaitu Synapta maculata, spesies ini merupakan salah satu mentimun laut atau sejenis teripang disebut juga sea cucumber. Spesies ini banyak ditemukan distasiun I yaitu didaerah budidaya dan di stasiun II yaitu ekosistem padang lamun. Synapta maculata merupakan spesies non ekonomis yang tidak banyak ditangkap oleh nelayan, diduga hal tersebut juga disebabkan karena spesies tersebut memiliki kemampuan melindungi diri dari perubahan kondisi lingkungan atau dari pemangsaan oleh predator serta gangguan lainnya (Hasanah dkk., 2012). Synapta maculata banyak ditemukan di beberapa habitat seperti: 1) Dasar laut berpasir dengan sedikit makroalga (makroalga $<5 \%$; 2) Dasar laut bepasir dengan cukup makroalga (makroalga 10-50\%); 3) Dasar laut berpasir dengan banyak makroalga (makroalga $>50 \%$ ); 4) Dasar laut berpasir dengan rumput laut $(>20 \%)$ dan mikroalga $(10-50 \%) ; 5)$ Dasar laut berpasir dengan makroalga dan koloni terumbu karang.

Rumput laut alami berasosiasi dengan ekosistem lamun, hal ini dilihat dari beberapa jenis spesies lamun yang ditemukan pada lokasi penelitian. Spesies lamun tersebut yaitu Halodule sp., Enhalus acoroides, dan Cymodocea serrulata.
Spesies rumput laut alami Hypnea spicifera ditemukan menempel disekitar ekosistem padang lamun. Fungsi ekologis padang lamun diantaranya adalah sebagai daerah asuhan, daerah pemijahan, daerah mencari makan, dan daerah untuk mencari perlindungan berbagai jenis biota laut seperti ikan, krustasea, moluska, echinodermata, dan sebagainya

\section{Simpulan}

Spesies rumput laut alami yang ditemukan di daerah budidaya rumput laut di perairan Pulau Serangan Denpasar Selatan berjumlah 12 spesies, dengan nilai kerapatan tertinggi 36,2 individu $/ \mathrm{m}^{2}$ pada stasiun III, spesies yang kerapatanya paling banyak adalah Padina australis dari divisi Phaeophyta (alga coklat) dan yang paling sedikit adalah Chaetomorpha linum dari divisi Chlorophyta (alga hijau). Kondisi substrat perairan yang kurang beragam berpengaruh terhadap keanekargaman rumput laut alami, sehingga keanekaragaman rumput laut alami Pulau Serangan menjadi rendah Indeks ekologi yaitu indeks keanekaragaman $\left(\mathrm{H}^{\prime}\right)$ dikategorikan rendah dengan nilai 1,5, indeks keseragaman (E) dikategorikan tinggi dengan nilai 0,78 indeks dominansi (C) dikategorikan rendah dengan nilai 0,29 (tidak ada dominansi). Komposisi jenis rumput laut alami dan biota berasosiasi antar stasiun bervariasi.

\section{Daftar Pustaka}

Arfah, H., \& Patty, S. I. (2014). Keanekaragaman dan biomassa makroalga di Perairan Teluk Kotania Seram Barat. Jurnal Ilmiah Platax, 2(2), 63-73.

Arthana, I. W., Wiyanto, D. B., Karang, I. W. G. A., \& Ernawati, N. M. (2017). Technical and SocioEconomic Problems of Seaweed Business in Nusa Lembongan, Bali. Udayana Journal of Social Sciences and Humanities, 1(1), 33-38.

Burdames, Y. (2014). Kondisi lingkungan Perairan budidaya rumput laut di Desa Arakan, Kabupaten Minahasa Selatan. Budidaya Perairan, 2(3), 69-75.

DKP Provinsi Bali. (2009). Produksi Rumput Laut di Bali turun 15,2\%. [online], (http://www.kabarbisnis.com), [diakses: 30 Oktober 2016].

Gutow, L., Petersen, I., Bartl, K., \& Huenerlage, K. (2016) Marine meso-herbivore consumption scales faster with temperature than seaweed primary production. Journal of Experimental Marine Biology and Ecology, 477, 80-85.

Hasanah, U., Suryanti, S., \& Sulardiono, B. (2012). Sebaran dan kepadatan teripang (Holothuroidea) di 
Perairan Pantai Pulau Pramuka. Journal of Management of Aquatic Resource, 1(1), 1-7.

Kadi, A. (2009). Makroalga di paparan terumbu karang Kepulauan Anambas. Jurnal Natur Indonesia, 12(1), 49-53.

Langoy, M. L. D., Saroyo, S., Dapas, F. N. J., Katili, D. Y., \& Hamsir, S. B. (2011). Deskripsi makroalga di Taman Wisata Alam Batuputih Kota Bitung. Jurnal Ilmiah Sains, 11(2), 220-224.

Li, W. C., Tse, H. F., \& Fok, L. (2016). Plastic waste in the marine environment: A review of sources, occurrence and effects. Science of the Total Environment, 566, 333349.

Lyons, D. A., Scheibling, R. E., \& Van Alstyne, K. L. (2010). Spatial and temporal variation in DMSP content in the invasive seaweed Codium fragile ssp. fragile: effects of temperature, light and grazing. Marine Ecology Progress Series, 417, 51-61.

Moussiopoulos, N., Achillas, C., Vlachokostas, C., Spyridi, D., \& Nikolaou, K. (2010). Environmental, social and economic information management for the evaluation of sustainability in urban areas: A system of indicators for Thessaloniki, Greece. Cities, 27(5), 377-384.

Nurmiyati, N. (2013). Keragaman distribusi dan nilai penting makroalga di Pantai Sepanjang Gunung Kidul. Bioedukasi, 6(1), 12-21.

Odum, E. P. (1993). Ecology and Our Endangered Life Support System. (2 ${ }^{\text {nd }}$ ed.). Sunderland, Massachusetts, USA: Sinauer.

Papalia, S., \& Arfah, H. (2013). Produktivitas biomasa makroalga di Perairan Pulau Ambalau Kabupaten Buru Selatan. Jurnal Ilmu dan Teknologi Kelautan, 5(2), 465-477.

Poeloengasih, C. D., Bardant, T. B., Rosyida, V. T., Maryana, R., \& Wahono, S. K. (2014). Coastal community empowerment in processing
Kappaphycus alvarezii: a case study in Ceningan Island, Bali, Indonesia. Journal of applied phycology, 26(3), 1539-1546.

Prabhakaran, S., Nair, V., \& Ramachandran, S. (2013). Marine waste management indicators in a tourism environment: Exploring possibilities for Semporna District, Sabah. Worldwide Hospitality and Tourism Themes, 5(4), 365-376.

Pratama, W., Dewi, S. C., Sari, I. Z. R., Hardiyati, A., \& Wajong, A. (2015). Distribution and abudance macroalgae in intertidal zone of Drini Beach Gunung Kidul DIY. The 3rd International Conference on Biological Science, 2(3), 514-517.

Sahayaraj, K., Rajesh, S., Asha, A., Rathi, J. M., \& Raja, P. (2014). Distribution and diversity assessment of the marine macroalgae at Four Southern Districts of Tamil Nadu, India. Indian Journal Of Geo-Marine Sciences, 43(3), 607-627.

Setyawan, I. B., Prihanta, \& W., Purwanti, E. (2014). Identifikasi keanekaragaman dan pola penyebaran makroalga di daerah Pasang Surut Pantai Pidakan Kabupaten Pacitan sebagai sumber belajar biologi. Jurnal Pendidikan Biologi Indonesia, 1(1), 78-88.

Silva, I. B., Fujii, M. T., \& Marinho-Soriano, E. (2012). Influence of tourist activity on the diversity of seaweed from reefs in Maracajaú, Atlantic Ocean, Northeast Brazil. Revista Brasileira de Farmacognosia, 22(4), 889-893.

Sukiman, Muspiah, A., Astuti, S. P., Ahyadi, H., \& Aryanti, E. (2014). Keanekaragaman dan distibusi spesies makroalga di wilayah Sekotong Lombok Barat. Jurnal Penelitian UNRAM, 18(2), 71-81.

Yu, Z., Hu, C., Sun, H., Li, H., \& Peng, P. (2013). Pond culture of seaweed Sargassum hemiphyllum in southern China. Chinese journal of oceanology and limnology, 31(2), 300-305.

(C) 2017 by the authors; licensee Udayana University, Indonesia. This article is an open access article distributed under the terms and conditions of the Creative Commons Attribution license (http://creativecommons.org/licenses/by/3.0/). 